\title{
Remobilization of Heavy Metals by Mangrove Leaves
}

\author{
Hanan Almahasheer ${ }^{1 *}$, Oscar Serrano ${ }^{2}$, Carlos M. Duarte ${ }^{3}$ and Xabier Irigoien ${ }^{3,4,5}$ \\ ${ }^{1}$ Department of Biology, College of Science, Imam Abdulrahman Bin Faisal University (IAU), Dammam, Saudi Arabia, ${ }^{2}$ Centre \\ for Marine Ecosystems Research, School of Science, Edith Cowan University, Joondalup, WA, Australia, ${ }^{3}$ Red Sea Research \\ Center, King Abdullah University of Science and Technology (KAUST), Red Sea Research Center, Makkah, Saudi Arabia, \\ ${ }^{4}$ Marine Research Department, AZTI - Tecnalia, Pasaia, Spain, ${ }^{5}$ IKERBASQUE, Basque Foundation for Science, Bilbao, \\ Spain
}

OPEN ACCESS

Edited by:

Alberto Basset,

University of Salento, Italy

Reviewed by:

Punyasloke Bhadury,

Indian Institute of Science Education and Research Kolkata, India

Akkur Vasudevan Raman,

Andhra University, India

*Correspondence:

Hanan Almahasheer halmahasheer@iau.edu.sa

Specialty section: This article was submitted to Marine Ecosystem Ecology, a section of the journal

Frontiers in Marine Science

Received: 14 September 2018 Accepted: 29 November 2018 Published: 13 December 2018

Citation:

Almahasheer $H$, Serrano $O$ Duarte CM and Irigoien X (2018) Remobilization of Heavy Metals by Mangrove Leaves.

Front. Mar. Sci. 5:484. doi: 10.3389/fmars.2018.00484
Several studies have been carried out on heavy metal pollution in mangrove ecosystems. However, the role of mangroves in heavy metal remobilization is still relatively unknown. On one side, mangrove woody organs and soils sequester heavy metals for long time periods, but on the other hand, senescence of mangrove leaves may return these metals collected by roots to the upper layers of the soil. Here, we analyzed the concentration of chemical elements (Al, As, Cd, Cr, Cu, Fe, Mn, Mo, Ni, Pb, Sr, V, and Zn) as a function of age in mangrove leaves to understand heavy metals retention by the plant and to quantify the amounts shed with senescing leaves. In addition, we estimated metal concentrations and stocks in mangrove soils. Our results revealed that the concentration of most metals increased with leaf age, resulting in the remobilization of metals stored in soil, thereby returning metals to the upper layers of the soil during senescence of mangrove leaves. Only Cu was reabsorbed prior to shedding of leaves, a mechanism similar to that described for nutrients in mangroves globally. These results provide key data to understand mangroves role in the dynamics of heavy metals.

Keywords: remediation, plants uptake, rhizosphere, deep soil, leaves age, Avicennia marina

\section{INTRODUCTION}

Inorganic pollutants such as heavy metals have both anthropogenic and earth crust origins (Lasat, 2002; Nagajyoti et al., 2010; Moore et al., 2011; Liu et al., 2018). Anthropogenic emissions in particular, have increased significantly over the last decades, e.g., in China 10 million ha of land have been polluted already (Chen et al., 2015). These metals are not degradable and get concentrated as they move up in the food chain (Wang et al., 2009; Patil et al., 2018). Nevertheless, plants usually absorb them from soil along with nutrients (Ovečka and Takáć, 2014; Novo et al., 2018), in a capacity that can be used to phytoremediate contaminated soils with heavy metals at low cost (Robinson et al., 2003; Yadegari, 2018). Many heavy metals (e.g., Co, Cu, Fe, Mn, Mo, Ni, Al, Rb, Ti, and $\mathrm{Zn}$ ) are not toxic and play a role as essential micronutrients for plant growth until they exceed a certain limit (Appenroth, 2010; Kabata-Pendias, 2010). Others are non-essential and often toxic to plant growth (e.g., $\mathrm{Cd}, \mathrm{Pb}, \mathrm{U}, \mathrm{Cr}, \mathrm{Ag}, \mathrm{Hg}$, and $\mathrm{Zr}$ ), while As and Se are metalloids yet are also toxic (Bothe, 2011; Shahid et al., 2013).

Green remediation is the use of plants to remove contaminants, and has been widely used, in particular in developing countries (Nouri et al., 2017). Mangroves have the potential to assist in the phytoremediation of coastal soils as they are able to grow in contaminated coastal environments (Nath et al., 2014; Chai et al., 2018). Indeed, mangrove ecosystems are very efficient at bio-accumulating metals, which together with their capacity to trap and immobilize soils resulting in 
soil elevation, points to an important potential role of mangrove ecosystems as metal filters and sinks in coastal areas (Wang S.-L. et al., 2013). In addition, metal concentrations in leaves reflect those in the soil and the environment, justifying its use as bio-indicators (Murray, 1985; Pinheiro et al., 2012).

However, the translocation of metals from the soil to mangrove organs, and leaves in particular, may result in the remobilization of heavy metals stored in the soil during detritus senescence. Although this will lead to a reduction of heavy metals in soils, shedding of e.g., mangrove leaves could transfer metals from deep soil layers into the soil surface and elsewhere in the ecosystem, so that rather than sequestering metals mangroves could be remobilizing pollutants within the ecosystem. Despite pollution in mangroves have been widely studied (Wang Y. et al., 2013; Zhang et al., 2014; Alzahrani et al., 2018; Kulkarni et al., 2018), and previous studies showed that mangroves have the capacity to reabsorb nutrients before shedding the leaves (Alongi et al., 2005; Zhou et al., 2010; Almahasheer et al., 2018), the fate of metals remains largely unknown (Saenger and McConchie, 2004). Therefore, the elemental fluxes between bio- and geospheres of mangrove ecosystems and in particular, the dynamics of heavy metals in mangrove leaves remain, to the best of our knowledge, unknown. Hence, the role of mangroves as sinks or sources of metals in polluted environments depends, to a large extent, of their capacity to reabsorb the metals before the leaves are shed.

Recently, we examined the capacity of Avicennia marina in the Red Sea to reabsorb N, P, and Fe prior to leave senescence, and despite evidence of Fe deficiency, mangroves had low resorption of Fe (42\%) compared to $\mathrm{N}$ and $\mathrm{P}$ (69 and $72 \%$, respectively; (Almahasheer et al., 2018). Whether these applies to other heavy metals or not is unknown.

Here we test the hypothesis that mangrove leaves reabsorb heavy metals before shedding them, as they do with $\mathrm{N}$ and $\mathrm{P}$ (Alongi et al., 2005; Zhou et al., 2010; Almahasheer et al., 2018). We do so by assessing the changes in heavy metal concentrations rates as a function of age in Red Sea mangrove (A. marina) leaves. Shall this hypothesis be supported, it will imply that mangroves would contribute to reducing the load of heavy metals in all soil layers, both surface and deep soils. We then evaluate the concentration and stock of heavy metals in the soil and compare it with their concentration in the overlying mangrove leaves by, estimating the leaf bio-concentration factor (BCF), to reflect the ability of plants to accumulate elements in leaves relative to soils.

\section{MATERIALS AND METHODS}

\section{Sampling Leaves and Soil in Mangrove Stands}

Soil cores and leaves from mangrove ecosystems were collected in November 2014 and March 2015, respectively, from four different locations in the Central Red Sea. Mangrove ecosystems were composed of monospecific stands of A. marina (Figure 1). At Thuwal Island $\left(22^{\circ} 16^{\prime} 54.42^{\prime \prime} \mathrm{N} 39^{\circ} 5^{\prime} 6.12^{\prime \prime} \mathrm{E}\right)$ and Khor Alkharar $\left(22^{\circ} 58^{\prime} 14.81^{\prime \prime} \mathrm{N} 38^{\circ} 50^{\prime} 44.27^{\prime \prime} \mathrm{E}\right)$ locations,

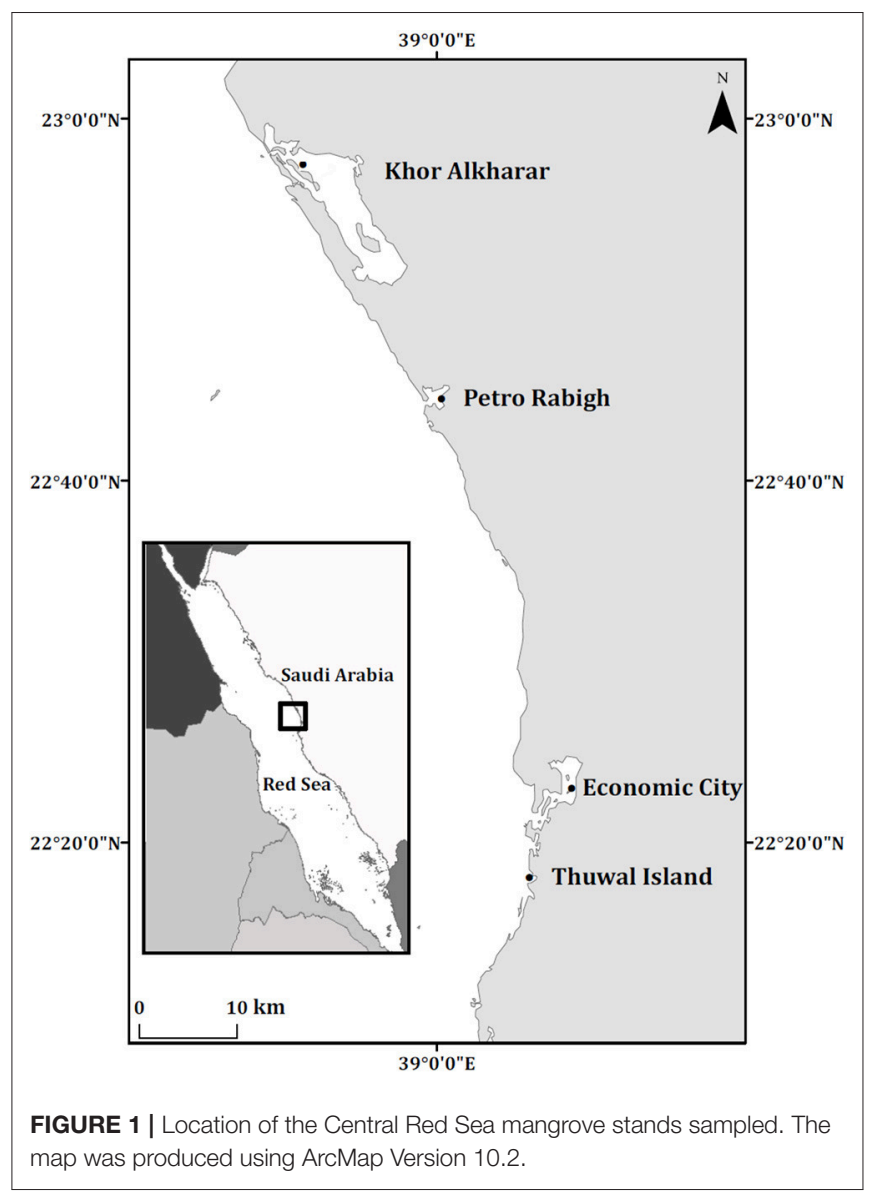

coastal development and human disturbances occur, whereas Economic City is a location under construction $\left(22^{\circ} 23^{\prime} 31.10^{\prime \prime} \mathrm{N}\right.$ $39^{\circ} 7^{\prime} 49.07^{\prime \prime} \mathrm{E}$ ) and Petro Rabigh is close to an oil refinery $\left(22^{\circ} 45^{\prime} 5.81^{\prime \prime} \mathrm{N} 39^{\circ} 0^{\prime} 46.90^{\prime \prime} \mathrm{E}\right)$. Details of study locations and environmental conditions are described in Almahasheer et al. (2016b, 2018).

A total of 91 leaves were collected across the four locations and sorted based on their location in the axillary shoot starting from the first leaf near the meristem to the last attached senescing leaf (Table 1). Each leaf was placed in an individual paper bag, and stored at 4 Celsius until analyses. A total of 26 cores soil cores were collected within mangrove stands across the four locations (eight cores at Thuwal Island, eight cores at Economic City, four cores at Petro Rabigh and six cores at Khor Alkharar) using $170 \mathrm{~cm}$ long PVC pipes. We used two types of corers; "whole corers" consisting in PVC pipes, and "port corers" consisting in $\mathrm{PVC}$ pipes with pre-drilled ports $(3 \mathrm{~cm}$ in diameter $)$ at $6 \mathrm{~cm}$ intervals [see Almahasheer et al. (2017) for further details]. The port cores were subsampled using a modified $60 \mathrm{~mL}$ syringe (and the volume of soil recorded), while the whole cores were cut lengthwise, and the soils inside were sliced at 1 or $3 \mathrm{~cm}$ thick slices using a ceramic knife. The slices were dried on the oven at $60^{\circ} \mathrm{C}$ until constant weight. Metal analyses were conducted in four to six soil depths per core within the top $30 \mathrm{~cm}$ of soil. 
TABLE 1 | Mean \pm SE for heavy metals concentration $\left(\mathrm{mg} \mathrm{g} \mathrm{DW}^{-1}\right)$ and content $\left(\mathrm{mg} \mathrm{DW} \mathrm{leaf}^{-1}\right.$ ) in Avicennia marina leaves from four different locations in the Central Red Sea, and the results from ANOVA and Tukey HSD post-hoc tests for differences among locations.

\begin{tabular}{|c|c|c|c|c|c|c|}
\hline & $\begin{array}{l}\text { Location } \\
\text { (n) }\end{array}$ & $\begin{array}{c}\text { Khor alkharar } \\
\text { (15) }\end{array}$ & $\begin{array}{c}\text { Economic city } \\
\text { (30) }\end{array}$ & $\begin{array}{r}\text { Petro rabigh } \\
\text { (27) }\end{array}$ & $\begin{array}{l}\text { Thuwal Island } \\
\text { (19) }\end{array}$ & $\mathbf{F}$ ratio \\
\hline \multirow{13}{*}{$\begin{array}{l}\text { Concentration } \\
\left(\mathrm{mg} \mathrm{g} \mathrm{DW}^{-1}\right)\end{array}$} & Al & $0.20778 \pm 0.02328^{b}$ & $0.37307 \pm 0.04527^{a}$ & $0.41386 \pm 0.04088^{a}$ & $0.33916 \pm 0.02444^{a b}$ & $3.82^{*}$ \\
\hline & As & $0.00216 \pm 0.00033^{a b}$ & $0.00215 \pm 0.00026^{b}$ & $0.00329 \pm 0.00028^{a}$ & $0.00273 \pm 0.00034^{a b}$ & $3.65^{\star}$ \\
\hline & $\mathrm{Cd}$ & $0.00021 \pm 0.00002^{\mathrm{a}}$ & $0.00017 \pm 0.00003^{a}$ & $0.00011 \pm 0.00002^{a}$ & $0.00020 \pm 0.00004^{a}$ & $1.87^{\mathrm{ns}}$ \\
\hline & $\mathrm{Cr}$ & $0.00087 \pm 0.00010^{a}$ & $0.00157 \pm 0.00025^{a}$ & $0.00123 \pm 0.00010^{a}$ & $0.00119 \pm 0.00009^{a}$ & $2.30^{\text {ns }}$ \\
\hline & $\mathrm{Cu}$ & $0.00218 \pm 0.00015^{a}$ & $0.00290 \pm 0.00024^{a}$ & $0.00306 \pm 0.00033^{a}$ & $0.00316 \pm 0.00076^{a}$ & $0.86^{\mathrm{ns}}$ \\
\hline & $\mathrm{Fe}$ & $0.26202 \pm 0.03370^{b}$ & $0.48587 \pm 0.06011^{a}$ & $0.55512 \pm 0.05563^{a}$ & $0.43934 \pm 0.02949^{a b}$ & $4.26^{\star \star}$ \\
\hline & $\mathrm{Mn}$ & $0.02324 \pm 0.00115^{b}$ & $0.02812 \pm 0.00229^{b}$ & $0.10157 \pm 0.01109^{a}$ & $0.02397 \pm 0.00191^{b}$ & $34.36^{\star \star}$ \\
\hline & Mo & $0.00282 \pm 0.00022^{a}$ & $0.00192 \pm 0.00029^{a b}$ & $0.00145 \pm 0.00024^{b}$ & $0.00178 \pm 0.00026^{a b}$ & $3.61^{*}$ \\
\hline & $\mathrm{Ni}$ & $0.00181 \pm 0.00033^{a}$ & $0.00212 \pm 0.00022^{a}$ & $0.00151 \pm 0.00014^{a}$ & $0.00141 \pm 0.00012^{a}$ & $2.80^{\star}$ \\
\hline & $\mathrm{Pb}$ & $0.00866 \pm 0.00081^{a}$ & $0.00872 \pm 0.00096^{a}$ & $0.00790 \pm 0.00065^{a}$ & $0.00844 \pm 0.00103^{a}$ & $0.19^{\text {ns }}$ \\
\hline & $\mathrm{Sr}$ & $0.05785 \pm 0.00187^{a}$ & $0.05976 \pm 0.00136^{a}$ & $0.05480 \pm 0.00149^{a}$ & $0.05848 \pm 0.00233^{a}$ & $1.84^{\mathrm{ns}}$ \\
\hline & V & $0.01645 \pm 0.00127^{a b}$ & $0.01469 \pm 0.00133^{b}$ & $0.02072 \pm 0.00169^{a}$ & $0.02127 \pm 0.00152^{a}$ & $4.74^{\star \star}$ \\
\hline & $\mathrm{Zn}$ & $0.01606 \pm 0.00529^{a}$ & $0.01034 \pm 0.00062^{a b}$ & $0.01689 \pm 0.00158^{a}$ & $0.00654 \pm 0.00050^{b}$ & $5.49^{\star \star}$ \\
\hline \multirow{13}{*}{$\begin{array}{l}\text { Content } \\
\text { (mg DW } \\
\text { leaf }^{-1} \text { ) }\end{array}$} & $\mathrm{Al}$ & $0.03540 \pm 0.00416^{b}$ & $0.08839 \pm 0.01063^{a}$ & $0.09646 \pm 0.01352^{a}$ & $0.06825 \pm 0.00981^{a b}$ & $4.56^{\star \star}$ \\
\hline & As & $0.00042 \pm 0.00008^{a}$ & $0.00059 \pm 0.00009^{a}$ & $0.00075 \pm 0.00009^{a}$ & $0.00058 \pm 0.00011^{a}$ & $1.65^{\mathrm{ns}}$ \\
\hline & Cd & $0.00004 \pm 0.00001^{a}$ & $0.00006 \pm 0.00001^{a}$ & $0.00003 \pm 0.00001^{a}$ & $0.00005 \pm 0.00002^{a}$ & $0.86^{\text {ns }}$ \\
\hline & $\mathrm{Cr}$ & $0.00015 \pm 0.00002^{b}$ & $0.00042 \pm 0.00009^{a}$ & $0.00030 \pm 0.00004^{a b}$ & $0.00026 \pm 0.00005^{a b}$ & $2.70^{\text {ns }}$ \\
\hline & $\mathrm{Cu}$ & $0.00040 \pm 0.00005^{b}$ & $0.00070 \pm 0.00007^{a}$ & $0.00059 \pm 0.00005^{a b}$ & $0.00054 \pm 0.00009^{a b}$ & $2.87^{\star}$ \\
\hline & $\mathrm{Fe}$ & $0.04362 \pm 0.00538^{b}$ & $0.11621 \pm 0.01414^{a}$ & $0.12953 \pm 0.01808^{a}$ & $0.09011 \pm 0.01336^{a b}$ & $4.95^{\star \star}$ \\
\hline & $\mathrm{Mn}$ & $0.00442 \pm 0.00058^{b}$ & $0.00724 \pm 0.00081^{b}$ & $0.02502 \pm 0.00373^{a}$ & $0.00565 \pm 0.00111^{b}$ & $18.42^{\star \star}$ \\
\hline & Mo & $0.00050 \pm 0.00006^{a}$ & $0.00064 \pm 0.00012^{a}$ & $0.00037 \pm 0.00008^{a}$ & $0.00035 \pm 0.00006^{a}$ & $2.08^{\mathrm{ns}}$ \\
\hline & $\mathrm{Ni}$ & $0.00031 \pm 0.00005^{b}$ & $0.00055 \pm 0.00008^{a}$ & $0.00036 \pm 0.00005^{a b}$ & $0.00030 \pm 0.00005^{a b}$ & $3.50^{\star}$ \\
\hline & $\mathrm{Pb}$ & $0.00160 \pm 0.00024^{a}$ & $0.00226 \pm 0.00036^{a}$ & $0.00172 \pm 0.00021^{a}$ & $0.00178 \pm 0.00033^{a}$ & $0.96^{\text {ns }}$ \\
\hline & $\mathrm{Sr}$ & $0.01039 \pm 0.00097^{a}$ & $0.01572 \pm 0.00157^{a}$ & $0.01244 \pm 0.00124^{a}$ & $0.01238 \pm 0.00184^{a}$ & $2.14^{\mathrm{ns}}$ \\
\hline & V & $0.00303 \pm 0.00040^{a}$ & $0.00405 \pm 0.00053^{a}$ & $0.00519 \pm 0.00069^{a}$ & $0.00511 \pm 0.00090^{a}$ & $1.90^{\text {ns }}$ \\
\hline & $\mathrm{Zn}$ & $0.00230 \pm 0.0004^{a b}$ & $0.00280 \pm 0.00036^{a b}$ & $0.00378 \pm 0.00054^{a}$ & $0.00132 \pm 0.00021^{b}$ & $5.52^{\star \star}$ \\
\hline
\end{tabular}

${ }^{\star}=0.05>P>0.01 ;{ }^{* *}=P<0.01 ; n s=P>0.05$. Locations sharing the same superscript letters do not differ among themselves for a particular element.

\section{Chemical Analysis}

All leaves were photographed and dried individually at $60^{\circ} \mathrm{C}$ oven until constant weight. Then $0.50 \mathrm{mg}$ of the leaf was digested with $6 \mathrm{ml}$ concentrated $\mathrm{HNO}_{3}$ and $2 \mathrm{ml}$ of $\mathrm{H}_{2} \mathrm{O}_{2}$ in Digi PREP digestion systems for $2 \mathrm{~h}$ at $95^{\circ} \mathrm{C}$, as described by Spalla et al. (2009). Around $200 \mathrm{mg}$ of soil was digested in $6 \mathrm{ml}$ of $\mathrm{HNO}_{3}$ and $2 \mathrm{ml}$ of HCL following EPA method 3052 (Kingston and Walter, 1995). All samples were left to cool and then diluted in MilliQ water to be subsequently analyzed by Inductively Coupled Plasma-Optical Emission Spectrometry (Varian Inc. model 720ES). Analyses of replicates and Quality Control Standards (Sigma-Aldrich, Inorganic Ventures and PerkinElmer's Pure Plusv), were carried out to ensure reproducibility of the results. In addition, spike recovery was evaluated to examine matrix effect, resulting a good recovery of heavy metals (grand average of 101\%) in Standards run together with both leaves and soil samples (Table 2). Additional, information of the ICP standard operating procedure (SOP) are in Table S1.

\section{Statistical Analysis}

The element content (mg DW leaf ${ }^{-1}$ ) was calculated as the product of element concentrations ( $\mathrm{mg}$ element $\mathrm{g} \mathrm{DW}^{-1}$ ) by the leaf dry mass (Lin and Wang, 2001). Leaf age was estimated using the plastochrone interval approach, i.e., the time in between development of a new node supporting a new leaf pair (Erickson and Michelini, 1957; Duarte et al., 1994; Coulter et al., 2001). Avicennia marina produced 9.6 nodes year ${ }^{-1}$ (Mean \pm SD) resulting in an estimated Plastocron interval (PI) of 38 days (Almahasheer et al., 2016c), the time interval between production of two consecutive leaf pairs along a branch.

To calculate the flux of elements in mangrove leaves (mg element $\mathrm{m}^{-2}$ year ${ }^{-1}$ ) we estimated the number of leaves shed annually per square meter using the leaf production and tree density measurements reported by Almahasheer et al. (2018). The BCF reflects the ability of plants to accumulate metals (Zhang et al., 2002), and was estimated as: BCF $=$ element leaves $/ \mathrm{element}_{\text {soil }}$. 
TABLE 2 | Average of \% recovery of heavy metals in Avicennia marina leaves and soil.

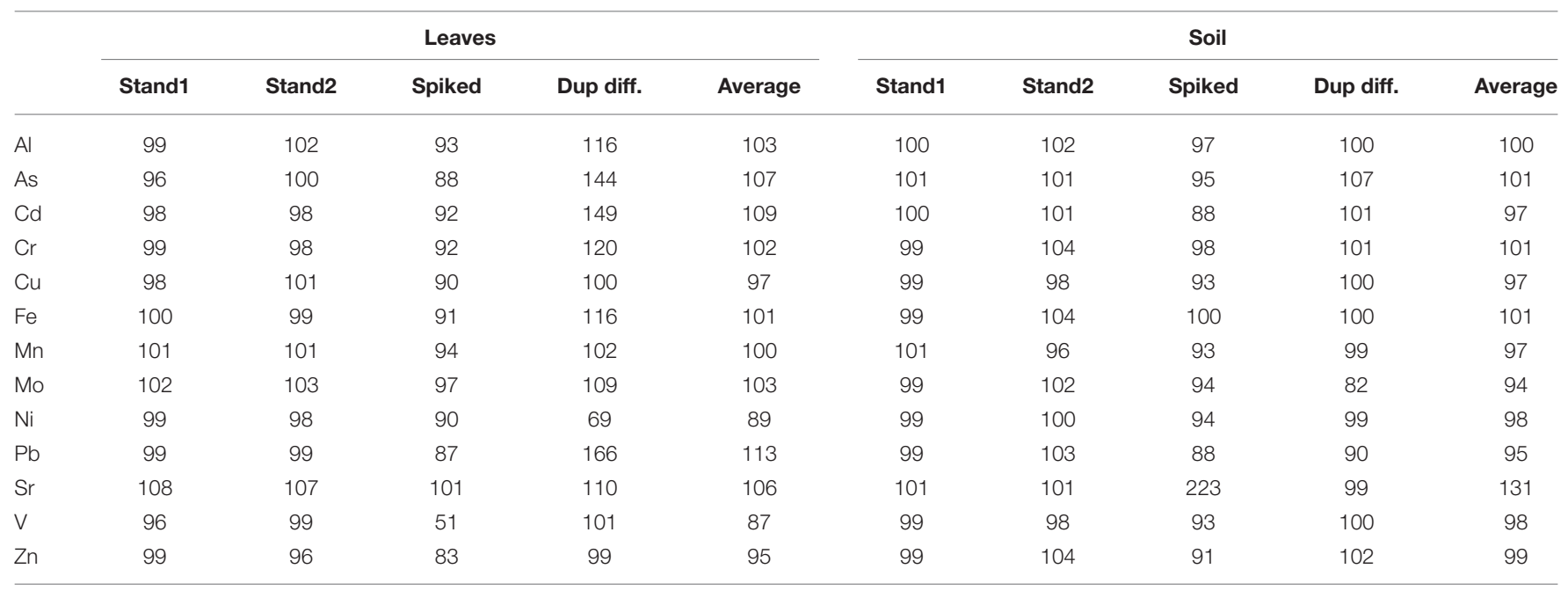

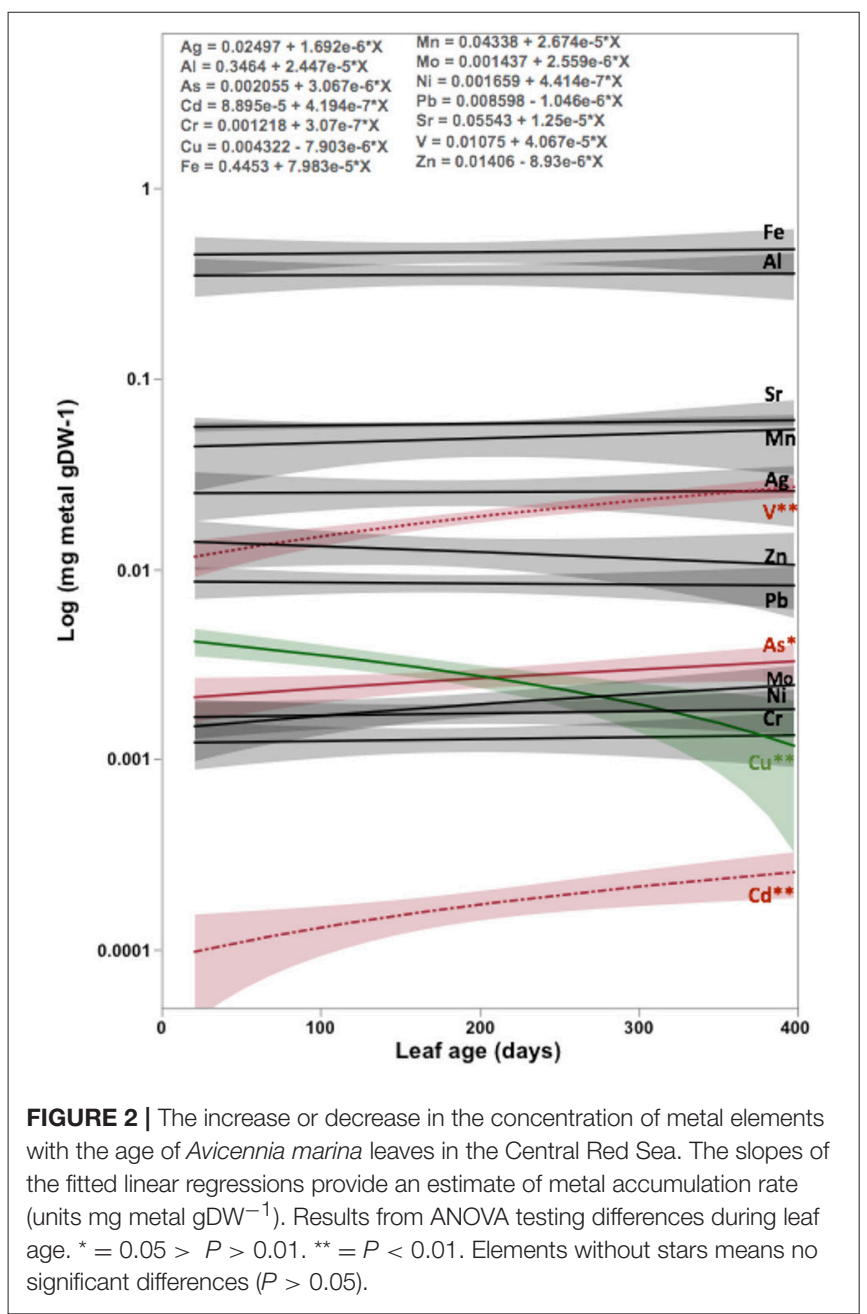

Metal stocks were calculated for each soil depth in each core by multiplying the soil dry bulk density by the metal concentration [see Almahasheer et al. (2017)]. Then to allow comparisons of

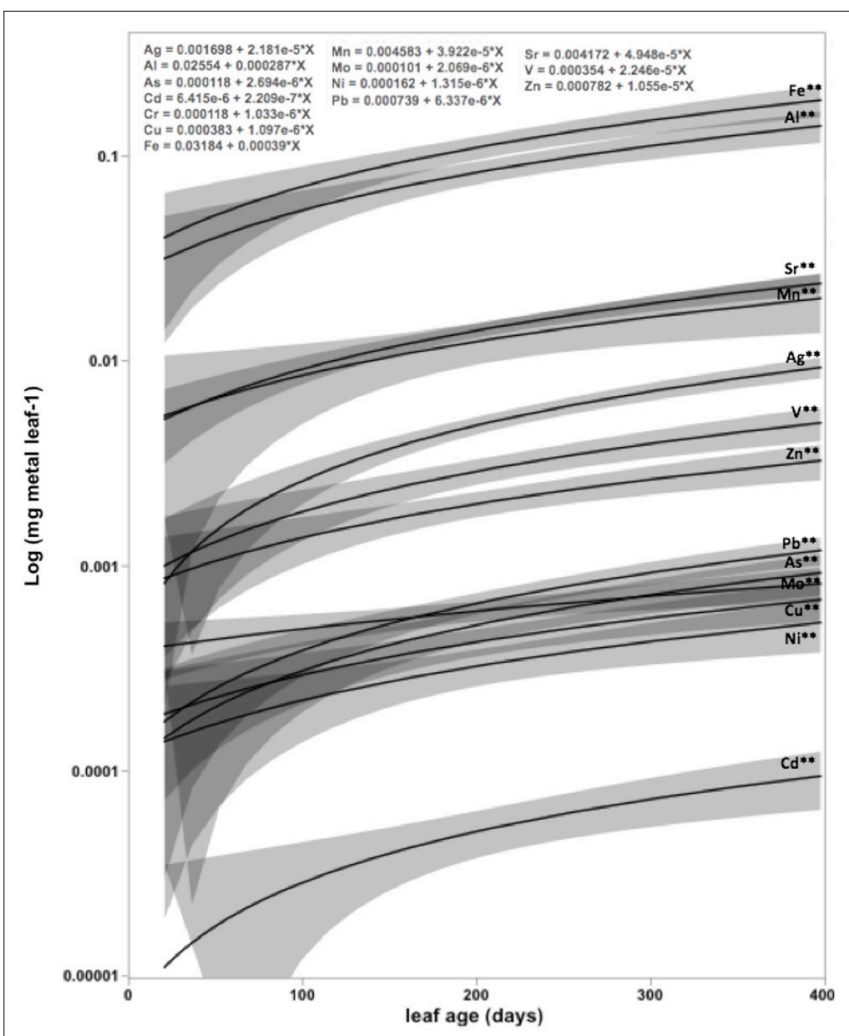

FIGURE 3 | The increase of metal content with the age of Avicennia marina leaves in the Central Red Sea. The slopes of the fitted linear regressions provide an estimate of metal accumulation rate (units mg metal leaf ${ }^{-1}$ ). Results from ANOVA testing differences during leaf age. ${ }^{*}=0.05>P>0.01$. ${ }^{\star *}=P<0.01$. Elements without stars means no significant differences $(P>0.05)$.

heavy metal stocks among locations, the cumulative mass (mass heavy metal per unit area) was calculated by multiplying the soil dry bulk density $\left(\mathrm{g} \mathrm{cm}^{-3}\right)$ by the metal concentration, and used to estimate the heavy metal stocks in $30 \mathrm{~cm}$ thick deposits. 


\section{A leaves}

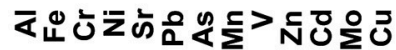

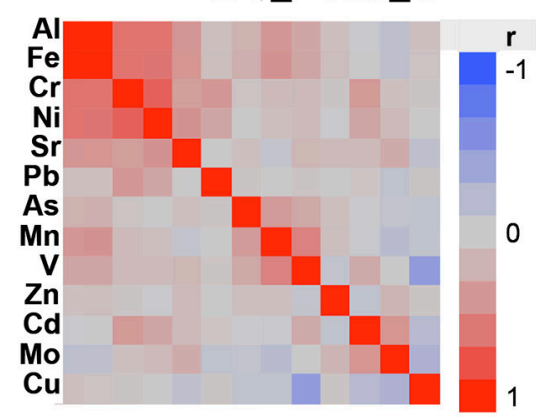

\section{B Soil}

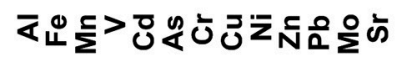

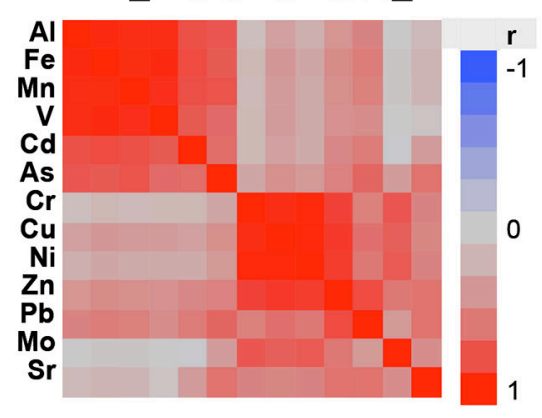

\section{c \\ leaves and soil}

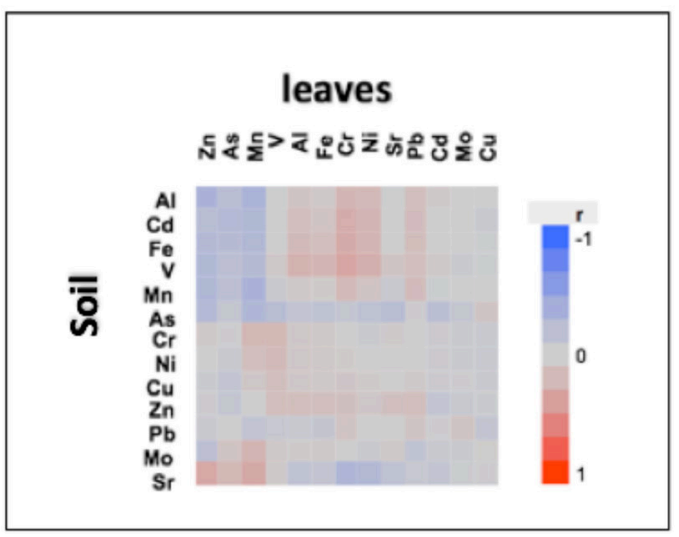

FIGURE 4 | Correlation heat plot showing the correlation (r) of metal concentrations in the leaves (A), soil (B), and between metals in leaves and soil (C).

Statistical analyses, including descriptive statistics, linear regression analyses of age vs. element content, general linear models to test differences among stands, and Tukey HSD posthoc test to assess pairwise differences were carried out using JMP Pro version 12.1.0., a statistical program developed by the SAS Institute.

\section{RESULTS}

The average concentration ( $\mathrm{mg} \mathrm{g} \mathrm{DW}^{-1}$ ) and contents (mg DW leaf $^{-1}$ ) of eight and six out of the 13 heavy metals analyzed in mangrove leaves differed significantly among locations, with Petro Rabigh supporting higher concentrations than Economic City. Indeed, both Petro Raibgh and Economic City locations contained higer concentrations of heavy metals than Khor Alkarar and Thuwal Island $(P<0.05$, Table 1, Tables S2,S3). Metal concentrations were independent of leaf age for most heavy metals, except for V, Cd, and As, which increased with leaf age, and $\mathrm{Cu}$ which decreased with leaf age $(P<0.01$, Figure 2$)$. Whereas, the content of all metals increased significantly with leaf age $(P<0.01$, Figure 3). Additionally, there were significant differences in the relationships (i.e., slopes) between metal contents and leaf age (i.e., accumulation rates) among locations (ANOVA, $P<0.05$, Tables S4,S5). Al, Fe, Cr, and $\mathrm{Ni}$ were significantly correlated among themselves in the leaves (Figure 4A, Table S6).

The average metal stocks in $30 \mathrm{~cm}$ thick-soils of eight and five out of the 13 heavy metals analyzed were significantly different among sites, with Petro Rabigh supporting higher concentration of most metals than Economic City, Khor Alkarar, and Thuwal Island (Table 3, Tukey HSD post-hoc test, $P<0.05$ ). Specifically, Al, Cd, Fe, Mn, and V stocks in 30-cm thicksoils were significantly higher in Petro Rabigh than in the other locations, and Sr concentration was higher in Thuwal Island compared to the rest of locations. The concentration of other metals (i.e., As, Mo, Cr, Ni, Cu, $\mathrm{Zn}$, and $\mathrm{Pb}$ ) did not differ significantly among locations (Figure 5, Tukey HSD post-hoc test, $P<0.05$ ). Two groups of metals were positively correlated among themselves in the soil: the first group included $\mathrm{Al}, \mathrm{Fe}, \mathrm{Mn}, \mathrm{Cd}$, and As, and the second group included $\mathrm{Cr}, \mathrm{Cu}, \mathrm{Ni}, \mathrm{Zn}$, and Mo (Figure 4B, Table S7). Even though metal concentrations in leaves and soils were not correlated (Figure 4C, Table S8), the BCF of most metals in the leaves was low, with leaf concentration half of the soil concentration, except for $\mathrm{V}$ and $\mathrm{Pb}$, where the concentration in leaves doubled and quadrupled the concentration in soils, respectively (Figure 6). 


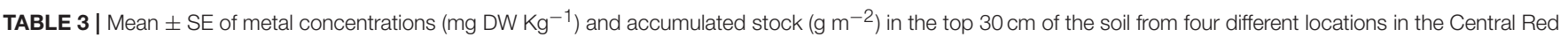
Sea, and the results from ANOVA Tukey HSD post-hoc tests for differences among locations.

\begin{tabular}{|c|c|c|c|c|c|c|c|}
\hline & Location & $\begin{array}{l}\text { Khor alkharar } \\
(N=6)\end{array}$ & $\begin{array}{l}\text { Economic city } \\
\qquad(N=8)\end{array}$ & $\begin{array}{l}\text { Petro rabigh } \\
\qquad(N=4)\end{array}$ & $\begin{array}{l}\text { Thuwal Island } \\
\qquad(N=8)\end{array}$ & $\begin{array}{l}\text { Average } \\
(N=26)\end{array}$ & $\begin{array}{c}\text { F ratio } \\
\text { (Location) }\end{array}$ \\
\hline \multirow{13}{*}{$\begin{array}{l}\text { Soil metal } \\
\text { concentration } \\
\left(\mathrm{mg} \mathrm{DW} \mathrm{Kg}^{-1}\right)\end{array}$} & $\mathrm{Al}$ & $2477.09 \pm 670.37^{a}$ & $4561.38 \pm 709.49^{a}$ & $7262.55 \pm 929.80^{a}$ & $2111.72 \pm 347.83^{a}$ & $3742.22 \pm 471.71$ & $10.7^{\star \star}$ \\
\hline & As & $7.03 \pm 1.06^{\mathrm{ab}}$ & $9.93 \pm 0.76^{a}$ & $7.49 \pm 1.06^{\mathrm{ab}}$ & $5.56 \pm 0.37^{b}$ & $7.54 \pm 0.50$ & $6.6^{\star *}$ \\
\hline & $\mathrm{Cd}$ & $0.24 \pm 0.04^{b}$ & $0.36 \pm 0.04^{b}$ & $0.56 \pm 0.06^{\mathrm{a}}$ & $0.27 \pm 0.02^{b}$ & $0.34 \pm 0.03$ & $12^{\star \star}$ \\
\hline & $\mathrm{Cr}$ & $22.81 \pm 7.65^{a}$ & $28.79 \pm 14^{\mathrm{a}}$ & $62.11 \pm 42.51^{a}$ & $68.52 \pm 61.45^{\mathrm{a}}$ & $44.76 \pm 19.87$ & $0.3^{\text {ns }}$ \\
\hline & $\mathrm{Cu}$ & $3.55 \pm 0.89^{a}$ & $6.77 \pm 1.67^{a}$ & $13.13 \pm 5.04^{\mathrm{a}}$ & $8.49 \pm 6.11^{a}$ & $7.53 \pm 2.08$ & $0.6^{\mathrm{ns}}$ \\
\hline & $\mathrm{Fe}$ & $3053.39 \pm 532.74^{b c}$ & $5682.10 \pm 820.21^{b}$ & $10501.47 \pm 1629.09^{a}$ & $2740.84 \pm 382.64^{c}$ & $4911.91 \pm 649.72$ & $16^{\star \star}$ \\
\hline & $\mathrm{Mn}$ & $45.47 \pm 6.92^{\mathrm{C}}$ & $100.85 \pm 15.02^{b}$ & $183.43 \pm 10.26^{a}$ & $43.37 \pm 7.15^{\mathrm{C}}$ & $83.09 \pm 11.24$ & $25.7^{\star \star}$ \\
\hline & Mo & $5.80 \pm 1.56^{\mathrm{a}}$ & $5.18 \pm 0.74^{a}$ & $1.82 \pm 0.61^{a}$ & $2.53 \pm 0.71^{a}$ & $3.99 \pm 0.56$ & $3.5^{\star}$ \\
\hline & $\mathrm{Ni}$ & $10.90 \pm 2.74^{a}$ & $15.38 \pm 5.16^{a}$ & $31.74 \pm 15.34^{a}$ & $25.85 \pm 21.01^{a}$ & $20.08 \pm 6.88$ & $0.4^{\mathrm{ns}}$ \\
\hline & $\mathrm{Pb}$ & $1.06 \pm 0.17^{\mathrm{a}}$ & $1.84 \pm 0.22^{\mathrm{a}}$ & $2.52 \pm 0.31^{\mathrm{a}}$ & $1.93 \pm 0.74^{\mathrm{a}}$ & $1.79 \pm 0.25$ & $1.1^{\mathrm{ns}}$ \\
\hline & $\mathrm{Sr}$ & $3881.66 \pm 313.97^{a b}$ & $3353.72 \pm 125.46^{b}$ & $3331.76 \pm 763.43^{a b}$ & $4561.03 \pm 321.31^{a}$ & $3843.66 \pm 190.98$ & $3.1^{\star}$ \\
\hline & V & $6.59 \pm 1.89^{b c}$ & $9.20 \pm 1.58^{\mathrm{ab}}$ & $16.19 \pm 3.35^{\mathrm{a}}$ & $3.04 \pm 0.59^{c}$ & $7.78 \pm 1.17$ & $8.9^{\star \star}$ \\
\hline & $\mathrm{Zn}$ & $12.22 \pm 1.36^{a}$ & $15.45 \pm 1.84^{\mathrm{a}}$ & $35.56 \pm 6.02^{\mathrm{a}}$ & $23.21 \pm 11.24^{\mathrm{a}}$ & $20.19 \pm 3.79$ & $1.4^{\mathrm{ns}}$ \\
\hline \multirow{13}{*}{$\begin{array}{l}\text { Soil metal stock } \\
\left(\mathrm{g} \mathrm{DW} \mathrm{m}^{-2}\right)\end{array}$} & $\mathrm{Al}$ & $469.81 \pm 60.93^{b}$ & $979.40 \pm 225.34^{a b}$ & $1587.80 \pm 316.85^{a}$ & $450.04 \pm 71.53^{b}$ & $792.52 \pm 116.48$ & $7.2^{\star \star}$ \\
\hline & As & $1.23 \pm 0.39^{a}$ & $1.94 \pm 0.32^{a}$ & $1.97 \pm 0.59^{a}$ & $1.14 \pm 0.16^{a}$ & $1.53 \pm 0.17$ & $1.8^{\mathrm{ns}}$ \\
\hline & $\mathrm{Cd}$ & $0.04 \pm 0.01^{b}$ & $0.07 \pm 0.01^{a b}$ & $0.12 \pm 0.03^{a}$ & $0.06 \pm 0.01^{b}$ & $0.07 \pm 0.01$ & $5^{\star \star}$ \\
\hline & $\mathrm{Cr}$ & $14.88 \pm 12.36^{a}$ & $4.80 \pm 1.17^{\mathrm{a}}$ & $6.51 \pm 2.94^{\mathrm{a}}$ & $6.26 \pm 3.46^{a}$ & $7.84 \pm 3$ & $0.5^{\mathrm{ns}}$ \\
\hline & $\mathrm{Cu}$ & $1.99 \pm 1.53^{\mathrm{a}}$ & $1.28 \pm 0.25^{\mathrm{a}}$ & $1.88 \pm 0.55^{\mathrm{a}}$ & $1.03 \pm 0.40^{a}$ & $1.46 \pm 0.37$ & $0.3^{\mathrm{ns}}$ \\
\hline & $\mathrm{Fe}$ & $581.86 \pm 121.98^{b}$ & $1184.91 \pm 250.26^{b}$ & $2230.68 \pm 391.20^{a}$ & $574.52 \pm 88.73^{b}$ & $1018.82 \pm 152.17$ & $10.4^{\star *}$ \\
\hline & $\mathrm{Mn}$ & $9.48 \pm 2.24^{b}$ & $21.34 \pm 4.65^{\mathrm{b}}$ & $38.91 \pm 6.44^{a}$ & $8.34 \pm 1.32^{b}$ & $17.31 \pm 2.76$ & $11.2^{\star \star}$ \\
\hline & Mo & $0.93 \pm 0.38^{a}$ & $0.86 \pm 0.2^{\mathrm{a}}$ & $0.32 \pm 0.1^{a}$ & $0.41 \pm 0.09^{a}$ & $0.66 \pm 0.12$ & $1.7^{\mathrm{ns}}$ \\
\hline & $\mathrm{Ni}$ & $5.90 \pm 4.52^{a}$ & $2.83 \pm 0.56^{a}$ & $4.25 \pm 1.38^{\mathrm{a}}$ & $2.64 \pm 1.23^{a}$ & $3.70 \pm 1.1$ & $0.5^{\mathrm{ns}}$ \\
\hline & $\mathrm{Pb}$ & $0.35 \pm 0.14^{a}$ & $0.41 \pm 0.06^{a}$ & $0.55 \pm 0.13^{a}$ & $0.37 \pm 0.14^{a}$ & $0.40 \pm 0.06$ & $0.4^{\mathrm{ns}}$ \\
\hline & $\mathrm{Sr}$ & $825.77 \pm 300.01^{a}$ & $673.55 \pm 104.66^{a}$ & $775.60 \pm 295.20^{a}$ & $1008.25 \pm 170.95^{a}$ & $827.36 \pm 99.67^{a}$ & $0.5^{\mathrm{ns}}$ \\
\hline & V & $1.01 \pm 0.18^{b}$ & $1.92 \pm 0.47^{b}$ & $3.76 \pm 0.67^{a}$ & $0.72 \pm 0.14^{\mathrm{b}}$ & $1.62 \pm 0.27$ & $10.5^{\star \star}$ \\
\hline & $\mathrm{Zn}$ & $4.36 \pm 2.21^{a}$ & $3.33 \pm 0.66^{a}$ & $5.86 \pm 0.78^{a}$ & $3.72 \pm 1.26^{\mathrm{a}}$ & $4.08 \pm 0.66$ & $0.5^{\mathrm{ns}}$ \\
\hline
\end{tabular}

${ }^{*}=0.05>P>0.01 ;{ }^{* *}=P<0.01 ; n s=P>0.05$. Locations sharing the same superscript letters do not differ among themselves for a particular element. $N$, number of cores.

\section{DISCUSSION}

The observed concentrations of heavy metals in the leaves and soils of A. marina in the Central Red Sea are generally in the lower range of values found in different mangrove species and environments observed around the planet (Agoramoorthy et al., 2008; Lai et al., 2010; Usman et al., 2013; Chaudhuri et al., 2014), Tables S9,S10, but similar to concentrations of $\mathrm{Cr}, \mathrm{Ni}, \mathrm{Pb}, \mathrm{Cd}$, and $\mathrm{Cu}$ reported for A. marina in other locations in the Red Sea (Alzahrani et al., 2018). Thus, suggesting that mangroves in the central Red Sea area are not under severe heavy metal pollution.

Whereas, previous studies reported similar or higher metal concentrations in mangrove roots and shoots compared to those in soils (Alongi et al., 2003; MacFarlane et al., 2003, 2007; Kaewtubtim et al., 2018; Kulkarni et al., 2018), However, in our study, we found heavy metals concentrations in the soil to be significantly higher than the leaves, in particular, we found that some of the metals (i.e., $\mathrm{Al}, \mathrm{Cd}, \mathrm{Fe}, \mathrm{Mn}$, and V) were significantly higher along the $30-\mathrm{cm}$ soil profile in Petro Rabigh, which could be due to industruial activities compared to the rest of locations. However, metal profiles in soils reveal significant fluctionations of metals inputs over time (Figure 5).

The role of leaf shedding as a source of metals to the environment should be taken into consideration when assessing the potential of mangroves as phytoremediation tools (Figure 7). Here we estimated that the metal remobilization with leaf shedding (i.e., transfer of deep-soil metal stocks into the soil surface) by mangroves in the Red Sea (occupying $\sim 135 \mathrm{~km}^{2}$; Almahasheer et al., 2016a totaled 120 tons of $\mathrm{Fe}, 91$ tons of $\mathrm{Al}$, 16 tons of $\mathrm{Mn}$, and $\mathrm{Sr}, 6$ tons of $\mathrm{V}, 3$ tons of $\mathrm{Zn}, 2$ tons of $\mathrm{Pb}$, 0.7 tons of As, 0.5 tons of Mo, 0.4 tons of $\mathrm{Cu}$ and $\mathrm{Ni}, 0.3$ tons of $\mathrm{Cr}$, and 0.05 tons of $\mathrm{Cd}$. These preliminary estimates show that mangroves could act as important sources of metals, particularly $\mathrm{Fe}$, to the Red Sea. Moreover, mangrove leaves in our Red Sea study sites cannot be considered as hyper-accumulators, since metals did not exceed $1 \%$ of the dried plant material (Baker and Brooks, 1989; Reeves et al., 2018), nor the concentrations of metals in above-ground parts exceeded their concentration in the soil (Baker, 1981). Further, our study relating the concentration of metals to leave age indicates that for most metals content 


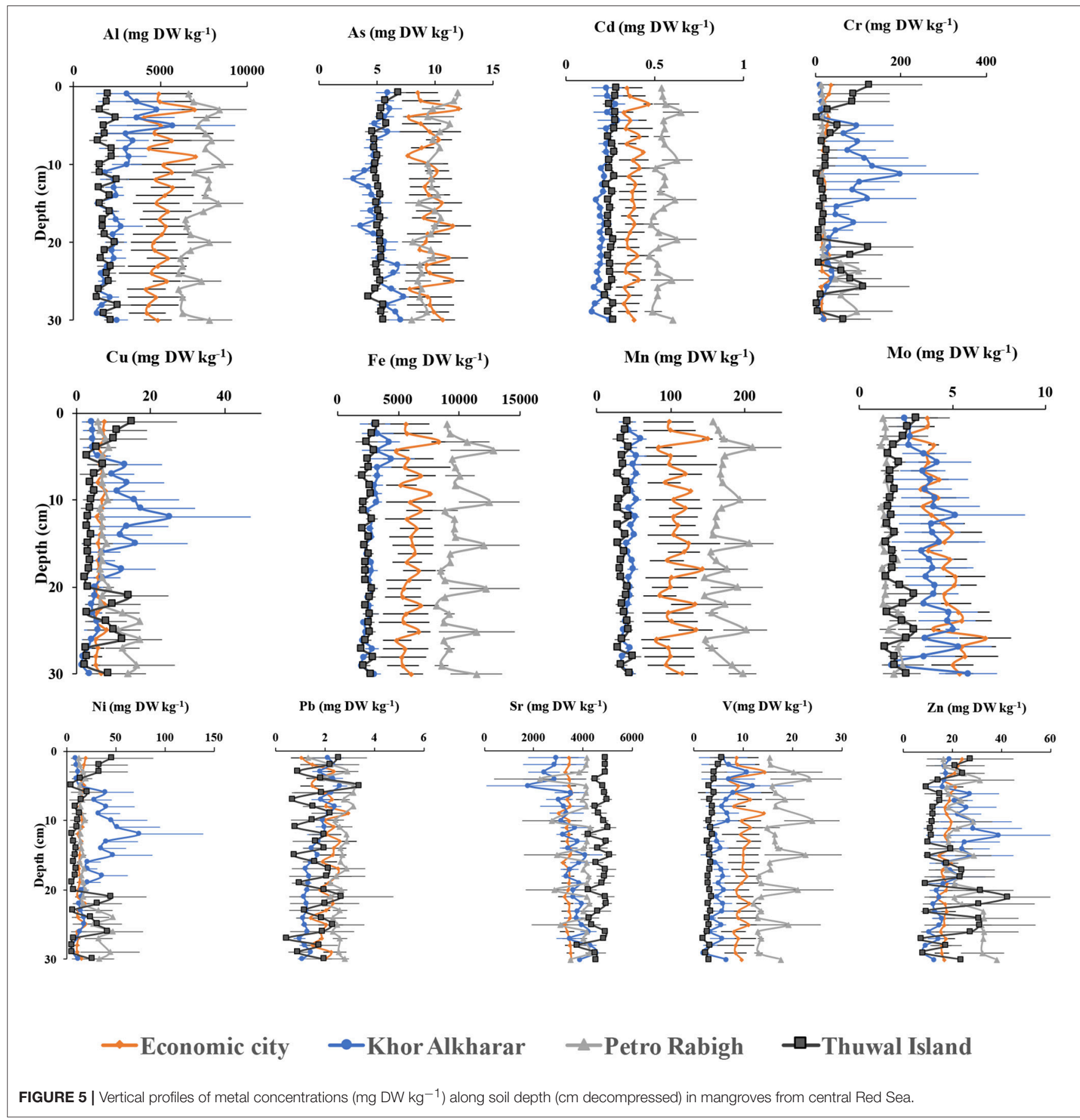

increases with leaf growth (Figure 2), showing no evidence of reabsorption before shedding. This implies that mangroves remobilize heavy metals that were stored deep in the soil by up taking them through their root system and bringing them back to the surface of the soil through leaves shedding.

Yet, three metals presented a different behavior. $\mathrm{Cu}$ concentration in leaves decreased with age, suggesting that A. marina reabsorbs about $51 \pm 16 \%$ of the $\mathrm{Cu}$ present in leaves before these are shed, potentially accumulating $\mathrm{Cu}$ in their above ground biomass as trees grow (Usman et al., 2013; Almahasheer, 2016). A similar effect for $\mathrm{Cu}$ concentrations has been observed in other mangrove species were concentrations were higher in young leaves than in mature leaves (Saenger and McConchie, 2004; Pinheiro et al., 2012). In plants, $\mathrm{Cu}$ is essential in various metabolic processes from photosynthesis to lignin synthesis, but at high concentrations it can be toxic and it is, therefore, under tight regulation (Pilon et al., 2006). The fact that $\mathrm{Cu}$ in mangrove leaves is being reabsorbed before leaves are 


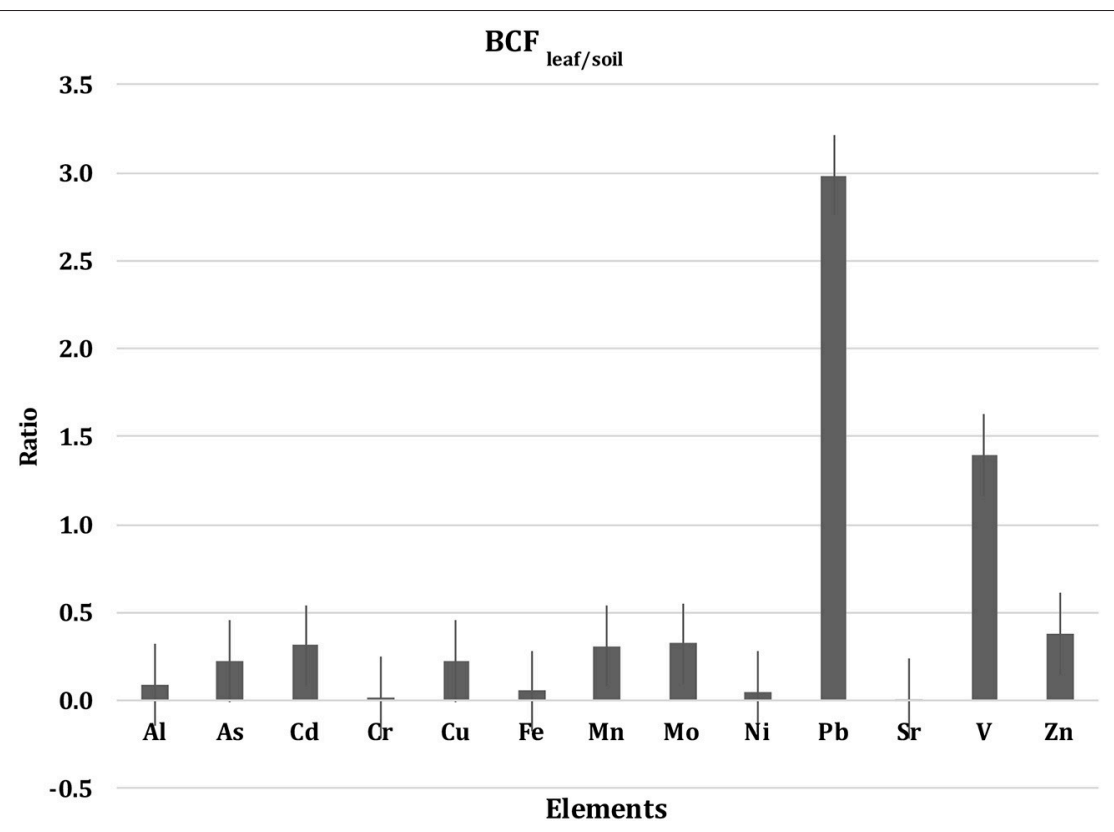

FIGURE 6 | Bioaccumulation factor (BCF), representing the ratio of the average metal concentrations in the leaf to soil, combining all four locations (Mean \pm SE).

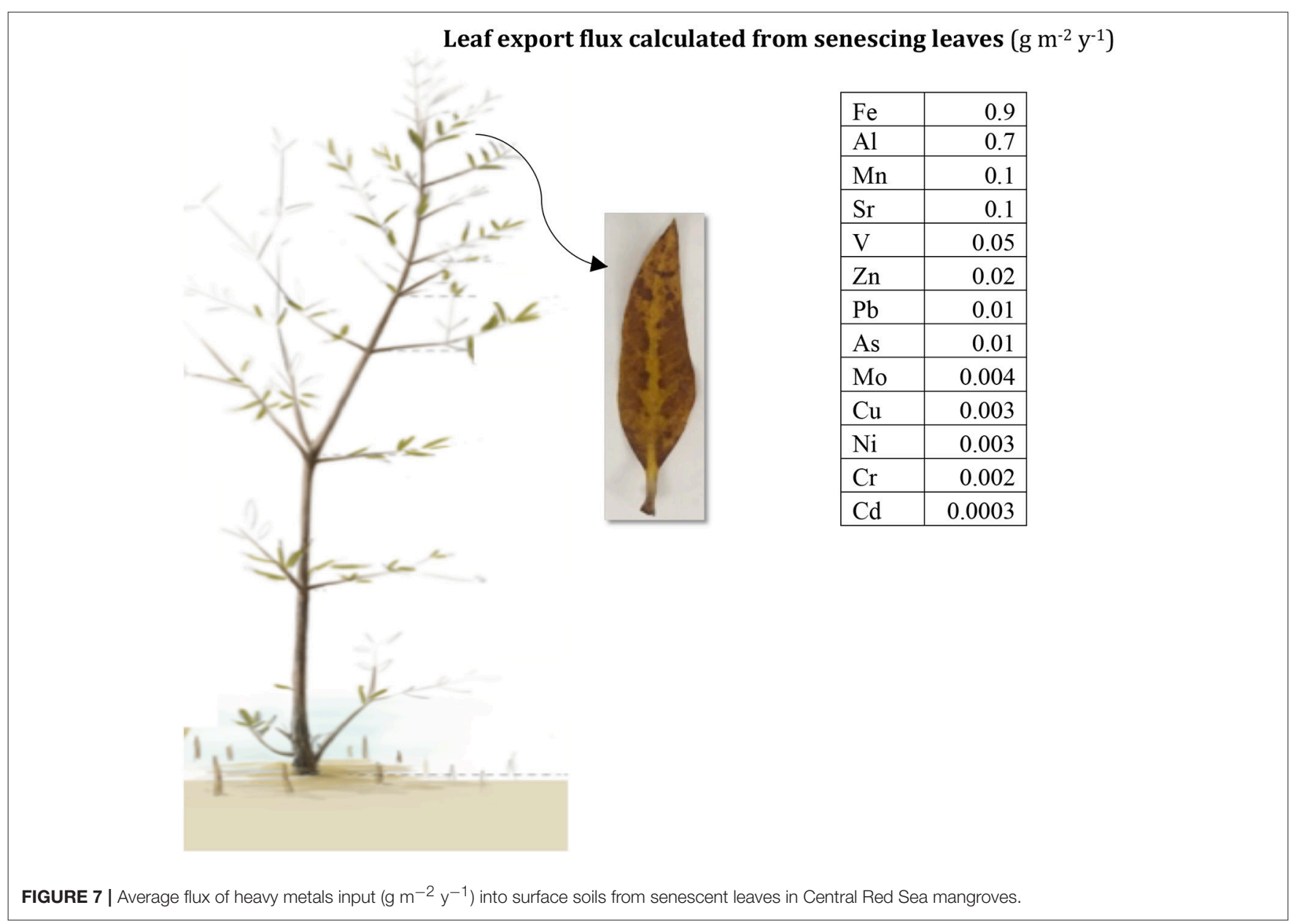


shed suggests that it might be a limiting chemical element for the growth of mangroves in the Central Red Sea, as supported by the low leaf concentration values $\left(3 \pm 1 \mathrm{mg} \mathrm{Kg}^{-1}\right)$ found at our study locations compared to those reported elsewhere e.g., $356 \mathrm{mg} \mathrm{Kg}^{-1}$ in Farasan Islands, (Usman et al., 2013) and $10-20 \mathrm{mg} \mathrm{Kg}^{-1}$ in Sydney, Australia (Nath et al., 2014; Birch et al., 2015). On the contrary, V, Cd, and As concentrations in the leaves increased with leaf age. Whether $\mathrm{V}$ is essential for plants is under debate, there is evidence that it has deleterious effects at high concentrations (Imtiaz et al., 2015). Both Cd and As are considered non-essential metals with toxic effects even at low concentrations (Finnegan and Chen, 2012; Gallego et al., 2012). The increasing concentration of both metals with leaf age suggests that $A$. marina has the capacity to detoxify itself by transferring these two elements to leaves, which will be shed, and therefore, A. marina could be considered as excluders for these two elements (Figure 2).

\section{CONCLUSIONS}

We demonstrate that mangroves remobilize metals buried deep in the soil into the environment by shedding the senescing leaves into the surface soil, which could either enter in food chains via leaf consumption or act as an important source of metals to the adjacent ecosystems depending on biogeochemical conditions and processes. Therefore, when used as phytoremediators, the

\section{REFERENCES}

Agoramoorthy, G., Chen, F.-A., and Hsu, M. J. (2008). Threat of heavy metal pollution in halophytic and mangrove plants of Tamil Nadu, India. Environ. Poll. 155, 320-326. doi: 10.1016/j.envpol.2007.11.011

Almahasheer, H. (2016). Ecosystem Services of Avicennia Marina in the Red Sea. P.hD. Dissertation. King Abdullah University of Science and Technology.

Almahasheer, H., Aljowair, A., Duarte, C. M., and Irigoien, X. (2016a). Decadal stability of Red Sea mangroves. Estuar. Coast. Shelf Sci. 169, 164-172. doi: 10.1016/j.ecss.2015.11.027

Almahasheer, H., Duarte, C. M., and Irigoien, X. (2016b). Nutrient limitation in central red Sea Mangroves. Front. Mar. Sci. 3:271. doi: 10.3389/fmars.2016.00271

Almahasheer, H., Duarte, C. M., and Irigoien, X. (2016c). Phenology and growth dynamics of Avicennia marina in the Central Red Sea. Sci. Rep. 6:37785. doi: $10.1038 /$ srep 37785

Almahasheer, H., Duarte, C. M., and Irigoien, X. (2018). Leaf nutrient resorption and export fluxes of Avicennia marina in the Central Red Sea area. Front. Mar. Sci. 5:204. doi: 10.3389/fmars.2018.00204

Almahasheer, H., Serrano, O., Duarte, C. M., Arias-Ortiz, A., Masque, P., and Irigoien, X. (2017). Low carbon sink capacity of Red Sea mangroves. Sci. Rep. 7:9700. doi: 10.1038/s41598-017-10424-9

Alongi, D., Clough, B., and Robertson, A. (2005). Nutrient-use efficiency in aridzone forests of the mangroves Rhizophora stylosa and Avicennia marina. Aquat. Bot. 82, 121-131. doi: 10.1016/j.aquabot.2005.04.005

Alongi, D. M., Clough, B. F., Dixon, P., and Tirendi, F. (2003). Nutrient partitioning and storage in arid-zone forests of the mangroves Rhizophora stylosa and Avicennia marina. Trees 17, 51-60. doi: 10.1007/s00468-0020206-2

Alzahrani, D. A., Selim, E.-M. M., and El-Sherbiny, M. M., (2018). Ecological assessment of heavy metals in the grey mangrove (Avicennia marina) and associated sediments along the red sea coast of saudi arabia. Oceanologia 60, 513-526. doi: 10.1016/j.oceano.2018.04.002 role of mangroves as heavy metal sinks through retention in the woody parts has to be evaluated taking into account the remobilization through leaves shedding.

\section{AUTHOR CONTRIBUTIONS}

$\mathrm{HA}, \mathrm{CD}$, and XI designed the study. HA and OS carried out the field and lab measurements. All authors contributed to data analysis and writing of the manuscript.

\section{FUNDING}

This research was supported by King Abdullah University of Science and Technology. OS was supported by an ARC DECRA (DE170101524).

\section{ACKNOWLEDGMENTS}

We thank the Costal and Marine Resources core lab for their help during the field work, as well Vijayalaxmi Dasari for soil analyses.

\section{SUPPLEMENTARY MATERIAL}

The Supplementary Material for this article can be found online at: https://www.frontiersin.org/articles/10.3389/fmars. 2018.00484/full\#supplementary-material

Appenroth, K.-J. (2010). What are "heavy metals" in plant sciences? Acta Physiologiae Plantarum 32, 615-619. doi: 10.1007/s11738-009-0455-4

Baker, A., and Brooks, R. (1989). Terrestrial higher plants which hyperaccumulate metallic elements. A review of their distribution, ecology and phytochemistry. Biorecovery 1, 81-126.

Baker, A. J. (1981). Accumulators and excluders-strategies in the response of plants to heavy metals. J. Plant Nutri. 3, 643-654. doi: 10.1080/01904168109362867

Birch, G., Nath, B., and Chaudhuri, P. (2015). Effectiveness of remediation of metal-contaminated mangrove sediments (Sydney estuary, Australia). Environ. Sci. Poll. Res. 22, 6185-6197. doi: 10.1007/s11356-014-3830-7

Bothe, H. (2011). "Plants in heavy metal soils," in Detoxification of Heavy Metals, eds S. Irena and V. Ajit (Berlin; Chicago, IL; Heidelberg: Springer), 35-57.

Chai, M., Li, R., Tam, N. F. Y., and Zan, Q. (2018). Effects of mangrove plant species on accumulation of heavy metals in sediment in a heavily polluted mangrove swamp in Pearl River Estuary, China. Environ. Geochem. Health. 6, 1-15. doi: 10.1007/s10653-018-0107-y

Chaudhuri, P., Nath, B., and Birch, G. (2014). Accumulation of trace metals in grey mangrove Avicennia marina fine nutritive roots: the role of rhizosphere processes. Mar Pollut Bull 79, 284-292. doi: 10.1016/j.marpolbul.2013.11.024

Chen, H., Teng, Y., Lu, S., Wang, Y., and Wang, J. (2015). Contamination features and health risk of soil heavy metals in China. Sci. Total Environ. 512, 143-153. doi: 10.1016/j.scitotenv.2015.01.025

Coulter, S. C., Duarte, C. M., Tuan, M. S., Tri, N. H., Ha, H. T., Giang, L. H., et al. (2001). Retrospective estimates of net leaf production in Kandelia candel mangrove forests. Marine Ecol. Progress Series 221, 117-124. doi: 10.3354/meps221117

Duarte, C. M., Marba, N., Agawin, N., Cebrian, J., Enriquez, S., Fortes, M. D., et al. (1994). Reconstruction of seagrass dynamics: age determinations and associated tools for the seagrass ecologist. Mar. Ecol. Prog. Series 107, 195-209. doi: 10.3354/meps107195

Erickson, R. O., and Michelini, F. J. (1957). The plastochron index. Am. J. Botany 44, 297-305. doi: 10.1002/j.1537-2197.1957.tb10544.x

Finnegan, P., and Chen, W. (2012). Arsenic toxicity: the effects on plant metabolism. Front. Physiol. 3, 182. doi: 10.3389/fphys.2012.00182 
Gallego, S. M., Pena, L. B., Barcia, R. A., Azpilicueta, C. E., Iannone, M. F., Rosales, E. P., et al. (2012). Unravelling cadmium toxicity and tolerance in plants: insight into regulatory mechanisms. Environ. Exp. Botany 83, 33-46. doi: 10.1016/j.envexpbot.2012.04.006

Imtiaz, M., Rizwan, M. S., Xiong, S., Li, H., Ashraf, M., Shahzad, S. M., et al. (2015). Vanadium, recent advancements and research prospects: a review. Environ. Int. 80, 79-88. doi: 10.1016/j.envint.2015.03.018

Kabata-Pendias, A. (2010). Trace Elements in Soils and Plants. Boca Raton, FL: CRC press; Taylor \& Francis Group.

Kaewtubtim, P., Meeinkuirt, W., Seepom, S., and Pichtel, J. (2018). Phytomanagement of radionuclides and heavy metals in mangrove sediments of Pattani Bay, Thailand using Avicennia marina and Pluchea indica. Mar. Pollut. Bull. 127, 320-333. doi: 10.1016/j.marpolbul.2017.12.021

Kingston, H., and Walter, P. (1995). Microwave Assisted Acid Digestion of Siliceous and Organically Based Matrices. EPA Draft Method 3052.

Kulkarni, R., Deobagkar, D., and Zinjarde, S. (2018). Metals in mangrove ecosystems and associated biota: a global perspective. Ecotoxicol. Environ. Safety 153, 215-228. doi: 10.1016/j.ecoenv.2018.02.021

Lai, D.-S., Lin, J.-B., Liu, W.-S., Pan, L.-K., Chu, K.-H., Chen, C.-Y., et al. (2010). Metal concentrations in sediments of the Tamsui River, flows through central metropolitan Taipei. Bull. Environ. Contamin. Toxicol. 84, 628-634. doi: 10.1007/s00128-010-9959-2

Lasat, M. M. (2002). Phytoextraction of toxic metals. J. Environ. Quality 31, 109-120. doi: 10.2134/jeq2002.1090

Lin, P., and Wang, W. q. (2001). Changes in the leaf composition, leaf mass and leaf area during leaf senescence in three species of mangroves. Ecol. Eng. 16, 415-424. doi: 10.1016/S0925-8574(00)00126-9

Liu, J., Chen, Y., Chao, S., Cao, H., Zhang, A., and Yang, Y. (2018). Emission control priority of PM2. 5-bound heavy metals in different seasons: a comprehensive analysis from health risk perspective. Sci. Total Environ. 644, 20-30. doi: 10.1016/j.scitotenv.2018.06.226

MacFarlane, G., Pulkownik, A., and Burchett, M. (2003). Accumulation and distribution of heavy metals in the grey mangrove,Avicennia marina (Forsk.) Vierh.: biological indication potential. Environ. Pollut. 123, 139-151. doi: 10.1016/S0269-7491(02)00342-1

MacFarlane, G. R., Koller, C. E., and Blomberg, S. P. (2007). Accumulation and partitioning of heavy metals in mangroves: a synthesis of fieldbased studies. Chemosphere 69, 1454-1464. doi: 10.1016/j.chemosphere.2007. 04.059

Moore, M. T., Kröger, R., and Jackson, C. R. (2011). The role of aquatic ecosystems in the elimination of pollutants. Ecol. Impacts Toxic Chem.1, 225-237. Available online at: http://citeseerx.ist.psu.edu/viewdoc/download? doi=10.1.1.493.7496\&rep=rep1\&type $=$ pdf

Murray, F. (1985). Cycling of fluoride in a mangrove community near a fluoride emission source. J. Appl. Ecol. 22, 277-285. doi: 10.2307/2403345

Nagajyoti, P., Lee, K., and Sreekanth, T. (2010). Heavy metals, occurrence and toxicity for plants: a review. Environ. Chem. Lett. 8, 199-216. doi: 10.1007/s10311-010-0297-8

Nath, B., Birch, G., and Chaudhuri, P. (2014). Assessment of sediment quality in Avicennia marina-dominated embayments of Sydney Estuary: the potential use of pneumatophores (aerial roots) as a bio-indicator of trace metal contamination. Sci. Total Environ. 472, 1010-1022. doi: 10.1016/j.scitotenv.2013.11.096

Nouri, H., Borujeni, S. C., Nirola, R., Hassanli, A., Beecham, S., Alaghmand, S., et al. (2017). Application of green remediation on soil salinity treatment: a review on halophytoremediation. Process Safety Environ. Prot. 107, 94-107. doi: 10.1016/j.psep.2017.01.021

Novo, L. A., Castro, P. M., Alvarenga, P., and da Silva, E. F. (2018). "Plant growth-promoting rhizobacteria-assisted phytoremediation of mine soils", in Bio-Geotechnologies for Mine Site Rehabilitation, eds M. N. V. Prasad, P. J. de Campos Favas, and S. K. Maiti (Amsterdam: Elsevier), 281-295.

Ovečka, M., and Takáč, T. (2014). Managing heavy metal toxicity stress in plants: biological and biotechnological tools. Biotechnol. Adv. 32, 73-86. doi: 10.1016/j.biotechadv.2013.11.011

Patil, H. K., Deshmukh, M. A., Bodkhe, G. A., and Shirsat, M. D. (2018). “Glassy carbon electrode modified with polyanilne/ethylenediamine for detection of copper ions," in AIP Conference Proceedings (New York, NY: AIP Publishing), 100034 .
Pilon, M., Abdel-Ghany, S. E., Cohu, C. M., Gogolin, K. A., and Ye, H. (2006). Copper cofactor delivery in plant cells. Curr. Opin. Plant Biol. 9, 256-263. doi: 10.1016/j.pbi.2006.03.007

Pinheiro, M. A. A., e Silva, P. P. G., de Almeida Duarte, L. F., Almeida, A. A. and Zanotto, F. P. (2012). Accumulation of six metals in the mangrove crab Ucides cordatus (Crustacea: Ucididae) and its food source, the red mangrove Rhizophora mangle (Angiosperma: Rhizophoraceae). Ecotoxicol. Environ. Safety 81, 114-121. doi: 10.1016/j.ecoenv.2012.05.004

Reeves, R. D., Baker, A. J., Jaffré, T., Erskine, P. D., Echevarria, G., and van der Ent, A. (2018). A global database for plants that hyperaccumulate metal and metalloid trace elements. New Phytologist 218, 407-411. doi: 10.1111/nph.14907

Robinson, B., Green, S., Mills, T., Clothier, B., Fung, L., Hurst, S., et al. (2003). "Assessment of phytoremediation as best management practice for degraded environments,"in Environmental Management Using Soil-plant Systems: Proceedings of the 16th Annual Workshop Held by the Fertilizer and Lime Research Centre, eds. L. D. Currie, R. B. Stewart and C. W. N. Anderson (Palmerston: Fertilizer and Lime Research Centre), 39-49.

Saenger, P., and McConchie, D. (2004). Heavy metals in mangroves: methodology, monitoring and management. Envis Forest Bull. 4:52. Available online at: https://pdfs.semanticscholar.org/790c/ 1a89573c54fc6d4cd4cea79882f4c56354e1.pdf

Shahid, M., Ferrand, E., Schreck, E., and Dumat, C. (2013). "Behavior and impact of zirconium in the soil-plant system: plant uptake and phytotoxicity," in Reviews of Environmental Contamination and Toxicology, Vol. 221. ed G. W. Ware (New York, NY: Springer), 107-127.

Spalla, S., Baffi, C., Barbante, C., Turretta, C., Cozzi, G., Beone, G., et al. (2009). Determination of rare earth elements in tomato plants by inductively coupled plasma mass spectrometry techniques. Rapid Commun. Mass Spectrom. 23, 3285-3292. doi: 10.1002/rcm.4244

Usman, A. R., Alkredaa, R. S., and Al-Wabel, M. (2013). Heavy metal contamination in sediments and mangroves from the coast of Red Sea: Avicennia marina as potential metal bioaccumulator. Ecotoxicol. Environ. Safety 97, 263-270. doi: 10.1016/j.ecoenv.2013.08.009

Wang, L. K., Chen, J. P., Hung, Y.-T., and Shammas, N. K. (2009). Heavy Metals in the Environment. Boca Raton, FL: CRC Press.

Wang, S.-L., Xu, X.-R., Sun, Y.-X., Liu, J.-L., and Li, H.-B. (2013). Heavy metal pollution in coastal areas of South China: a review. Mar. Poll. Bul. 76, 7-15. doi: 10.1016/j.marpolbul.2013.08.025

Wang, Y., Qiu, Q., Xin, G., Yang, Z., Zheng, J., Ye, Z., et al. (2013). Heavy metal contamination in a vulnerable mangrove swamp in South China. Environ. Monitor. Assess. 185, 5775-5787. doi: 10.1007/s10661-012-2983-4

Yadegari, M. (2018). Performance of purslane (Portulaca oleracea) in nickel and cadmium contaminated soil as a heavy metals-removing crop. Plant Physiol. 8, 2447-2455. doi: 10.22034/ijpp.2018.540891

Zhang, W., Cai, Y., Tu, C., and Ma, L. Q. (2002). Arsenic speciation and distribution in an arsenic hyperaccumulating plant. Sci. Total Environ. 300, 167-177. doi: 10.1016/S0048-9697(02)00165-1

Zhang, Z.-W., Xu, X.-R., Sun, Y.-X., Yu, S., Chen, Y.-S., and Peng, J.-X. (2014). Heavy metal and organic contaminants in mangrove ecosystems of China: a review. Enviro. Sci. Pollut. Res. 21, 11938-11950. doi: $10.1007 / \mathrm{s} 11356-014-3100-8$

Zhou, H.-C., Wei, S.-D., Zeng, Q., Zhang, L.-H., Tam, N. F., and Lin, Y.-M. (2010). Nutrient and caloric dynamics in Avicennia marina leaves at different developmental and decay stages in Zhangjiang River Estuary, China. Estuar. Coastal Shelf Sci. 87, 21-26. doi: 10.1016/j.ecss.2009.12.005

Conflict of Interest Statement: The authors declare that the research was conducted in the absence of any commercial or financial relationships that could be construed as a potential conflict of interest.

Copyright (C) 2018 Almahasheer, Serrano, Duarte and Irigoien. This is an open-access article distributed under the terms of the Creative Commons Attribution License (CC $B Y)$. The use, distribution or reproduction in other forums is permitted, provided the original author(s) and the copyright owner(s) are credited and that the original publication in this journal is cited, in accordance with accepted academic practice. No use, distribution or reproduction is permitted which does not comply with these terms. 